\title{
Geochronology on Cenozoic volcanic rocks of a profile Linzhou Basin, Tibet, China and their geological implications
}

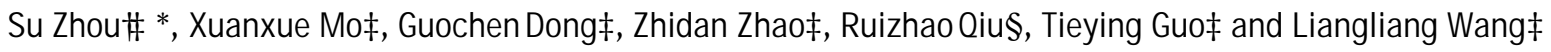 \\ † Key Laboratory of Lithospheric Tectonics Deep-level process and Exploration Ministry of Education, PR CHINA \\ ¥ China University of Geosciences (Beijing), 100083, PR CHINA \\ $\$$ Institute of Geology, Chinese Academy of Geological Sciences, Beijing, 100037, PR CHINA
}

* To whom correspondence should be addressed. E-mail: zhousu@cugb.edu.cn

Linzizong volcanic rocks are widely distributed in the GangdeseNyainqentanglha tectono-magmatic belt of Tibet. They contain plenty of information on the closure of the Neotethyan Ocean and the subsequent intracontinental collision. Much research on stratigraphic sequences and geochronology has been conducted, and has helped in understanding the volcanic series of Linzizong and southern Tibet. It has also provided a sound foundation for the present study. Thus far, the formation ages of Linzizong volcanic rocks and other rock units in them are still controversial. While some results indicated that they formed in Late Cretaceous (Liu 1993; Bureau of Geology and Mineral Resources of Xizang Autonomous Region 1993), others suggested that they formed in Paleo-Eocene. Moreover, although numerous radiochronological results have been published (Wang et al. 1990), these results were not associated with in-situ stratigraphical study. Therefore, it is difficult to correlate geochronological data with stratigraphical units and, consequently, a complete geochronology framework of this region is yet to be established.

Linzhou volcanic-sedimentary basin is the main site of Linzizong volcanic rocks with good exposure of interlayered volcanic- sedimentary sections and a clear unconformity with the underlying rock units. Most previous work on Mesozoic and Cenozoic volcanic rocks along the Gangdese-Nyainqentanglha belt has been cross-referenced with Linzhou Basin. Hence, Linzhou volcanic-sedimentary basin is critical for establishing the geochronology framework of Linzizong volcanic rocks and other volcanic rocks along the Gangdese-Nyainqentanglha belt. Detailed petrological and geochemical studies suggested that the characteristics of magmas, types of tectono-magmatism, as well as the geodynamic environments of Linzizong volcanic rocks have changed through time. The Dianzhong Formation in the lower part mainly consists of medium potassium calc-alkaline and metaluminous volcanic rocks, whereas the Nianbo and Pana Formations in the middle and upper parts mainly consist of Krich calc-alkaline to shoshonitic rocks, indicating the process of gradual crustal thickening. Trace and rare earth element geochemistry shows dual characters of continental margin-and intra-continental volcanic rocks. From the lower part to the upper part, the arc signature became weaker, and the intra-continental signature became more prominent. The Pana Formation at the latest stage was indistinguishable from the typical post-collision volcanic rocks of Tibetan plateau. $\mathrm{Nd}-\mathrm{Sr}-\mathrm{Pb}$ isotopes of these late stage rocks indicate isotopic mixing between the subducted oceanic crust and oceanic lithospheric mantle and between the continental crust and sub-continental lithospheric mantle. That is, there may be interaction between mantle and crust as well as between oceanic and continental mantle indicating transitional geodynamic settings from subduction regime of Neo-Tethyan ocean to that of continental collision. Thus Linzizong volcanic rocks may record the termination of subduction, the onset and the end of collision, and the initiation of the post-collisional stage, which is coupled with the collision between the Indian and Asian continents.

The purpose of this work is to clarify the geochronological framework of the Linzizong volcanic rocks and to integrate the geochronological data with stratigraphical studies in order to shed light on the tectono-magmatism related to the major collision event between the Indian- Asian continents. We carried out systematic ${ }^{40} \mathrm{Ar} /{ }^{39} \mathrm{Ar}$ geochronlogical dating of the volcanic rocks from all three formations in Linzizong series and the dyke rocks intruded in them. In order to define the precise time for the end of the regional angular unconformity, samples from Maqu profile are also collected and dated.

Linzhou volcanic basin is in the eastern part of Gangdese in Tibetan Plateau, about $60 \mathrm{~km}$ northeast of Lhasa. The basin is of an irregular elliptical form trending approximately $\mathrm{E}-\mathrm{W}$, and covers an area of about $230 \mathrm{~km}^{2}$. Within the basin the Linzizong volcanic series occurs annularly with their strata flatly dipping northwards, generally between $20^{\circ}$ and $25^{\circ}$. The volcanic sequences consist of Dianzhong, Nianbo and Pana Formations upwards in the column. Dianzhong Formation is primarily distributed in the south of the basin and consists of andesite, dacites, trachy-andesite flows and pyroclastic rocks. The rhyolitic pyroclastic rocks in the lower part (southwest part of the region) is about 800 -meter thick, constituting several rhythmic eruption cycles. Pebbles of the basal conglomerate of various thicknesses are likely from the underlying Shexing Formation. The Nianbo Formation is zonally distributed in the central part of the basin, and is comprised of thin-bedded limestone and rhyolitic tuff. The thickness of Nianbo and Shexing Formations covaries inversely eastwards. Thin limestone layers are thickened eastward from Xiagunba, whereas the number of rhyolitic tuff layers and layer thickness increase westwards. In the eastern part of the basin, there are abundant andesite, shoshonite and relevant pyroclastic rock assemblages in the upper part of Nianbo Formation with uabergine pelite at the summit. The Pana Formation mainly cropped out in the north part of the basin and is in elliptic shape in the center, consisting of a set of thick acidic ignimbrite layers. In the upper part volcanic rocks are interbeded with fluvial and lacustrine sediments. The Pana Formation was truncated by Ranmojiang Fault in the north. The contact relationship between the formations in the Linzizong series ranges from parallel unconformity to slightly angular unconformity.

On the basis of detailed geological investigation, especially the study of stratigraphical sequences, seven volcanic rock samples were collected from the series from the bottom to near the top. In addition, a sample was collected from a dyke intruding into the Linzizong volcanic rocks in the western part of the basin.

Samples were wrapped in Cd shielding to absorb slow neutrons and then irradiated in the 49-2 Fast Neutron Nuclear Reactor at Institute of Nuclear Energy of China with an irradiation standard ZBH-25 ( $t=133.2 \mathrm{Ma}$ ) for 8 hours and received a total 
of $1.86 \times 10^{17}$ fast neutrons per $\mathrm{cm}^{2}$. Incremental step-heating analysis was performed at Micromass 5400 static vacuum mass spectrometer in the Geochronology Laboratory at China University of Geoscience (Beijing). Heating of a sample to release argon was achieved using a resistance furnace. The released gas was purified using Titanium sponge furnace at $800{ }^{\circ} \mathrm{C}$, and let into the extraction line where it was continuously purified using the Ti-furnace (which can be switched off to let it cool) and two Sorb-AC getters (one operated at $400{ }^{\circ} \mathrm{C}$ and the other at room temperature) to remove active gases for another $20 \mathrm{~min}$. The purified gas was let into the mass spectrometer and measured in turn on the trap with a current of $200 \mu \mathrm{A}$ and an accelerating voltage of $4.5 \mathrm{kV}$. Measured mass peak intensities were corrected for mass discrimination, radioactive decays of ${ }^{37} \mathrm{Ar}$, and interfering isotopes from neutron reactions on $\mathrm{K}$ and $\mathrm{Ca}$ using the formulas in McDougall and Harrison (1999). The correction factors were, ${ }^{36} \mathrm{Ar} /{ }^{37} \mathrm{Ar}(\mathrm{Ca})=0.0002398,{ }^{39} \mathrm{Ar} /{ }^{37} \mathrm{Ar}(\mathrm{Ca})=0.0008,{ }^{40} \mathrm{Ar} /{ }^{39} \mathrm{Ar}(\mathrm{K})=$ 0.004782 . The ${ }^{40} \mathrm{Ar}$ blank was $2-5 \times 10^{-10} \mathrm{~cm}^{3} \mathrm{STP}$ at $1500{ }^{\circ} \mathrm{C}$. Determination of the background and careful checking of the peak position were routinely performed. Correction for mass discrimination was based on multiple measurements of atmosphere. The apparent age for each gas extraction was calculated using the decay constant of $5.543 \times 10^{-10} \mathrm{yr}^{-1}$ and assuming an initial ${ }^{40} \mathrm{Ar} /{ }^{39} \mathrm{Ar}$ value of 295.5 . A $2 \%$ uncertainty was assigned to the apparent age, reflecting the propagated error in all correction factors and the J parameter Classical age spectra were plotted against the cumulative ${ }^{39} \mathrm{Ar}$ fraction and isochron ages were calculated using the ISOPLOT program provided by Dr K. Ludwig of the Berkeley Geochronology Center, USA.

From one sample from Nianbo Formation, and four samples each from Dianzhong and Pana Formations, a simple age sequence for Linzizong volcanic activities can be summarized as follows: Dianzhong Formation formed at $64.43 \mathrm{Ma}$ to ca.60 Ma, Pana Formation at $48.73 \mathrm{Ma}$ to $43.93 \mathrm{Ma}$, with Nianbo Formation in between the two formations. The age of $54 \mathrm{Ma}$ for sample N-9 in Nianbo Formation agrees with the evidence of Paleocene-Eocene fossils of Amnicola sp., Bythinia sp., Ostracods: Homocucypris cyprinortus(Heterocypris), Syclocypris sp., Cyprisotus., Cyprois sp., Sinocypris sp. in the Formation. The age spectrum of the K-feldspar separate from rhyolitic dyke in Pana Formation is $51.6 \pm 2.6 \mathrm{Ma}$.

All of these show that (i) the age and duration of Linzizong volcanics are well constrined to be between 40-65 Ma, and (ii) the establishment of a geochronology framework on the Linzizong volcanic rocks at Linzhou basin would serve as a reference for understanding regional volcanic rocks.
Linzizong volcanic activities are synchronous with the dominant phase of the Gangdese pluton (65-40 Ma). One explanation is that both were due to the magmatic response to the Indo-Asian collision. There are great differences in sedimentary facies, tectonic deformation and structural styles across the unconformity. The Linzizong volcanic series are characterized by continental sedimentary facies with steady flatlying strata, the Shexing Formation is characterized by marine facies and complicated folding structures, reflecting the superposition of multiple tectonic activities. All these features are indicative of a major geotectonic event for this unconformity. The lowermost time limit of Linzizong volcanic rocks roughly coincides with the beginning of the collision between Indian and Asian continents at $\sim \mathrm{K} / \mathrm{T}$ boundary $(\sim 65 \mathrm{Ma})$ as argued from stratigraphy, paleontology as well as paleomagnetism studies (Ding 2003). Therefore, we argue that Linzizong volcanic activities are initiated by the collision.

\section{Acknowledgments}

We thank Prof. Luo Xiuquan for sharing his expertise in dating techniques, constructive review on an early version of this manuscript. We are grateful to Dr JiangWan for assistance with M-01 sample collection. We are indebted to Prof. Dai Tongmo and Li Daming for their helpful discussions and the interpretation of the data, and to Prof. You Zhendong and Dr. Gan Guoliang for improvements to the English. The project is financially supported by the Key Laboratory of Lithospheric Tectonics and Exploration, China University of Geosciences, Ministry of Education, China (Grant No.2003009), the National Natural Science Foundation of China and the National key Project for Basic Research on Tibetan Plateau (40103003, 49802005, 49772107, and G1998040800, 2002CB412600)

\section{References}

Liu HF. 1993. Division of Linzizong volcanic series and its geochronology in Lhasa area. Xizang Geology 2:59-69

Bureau of Geology and Mineral Resources of Xizang Autonomous Region. 1993. People's Republic of China Ministry of Geology and mineral resources geological memoirs - Regional Geology of Xizang (Tibet). Beijing: Geological Publishing House. P 237-463

Wang S. 1990. Volcanic rocks in central-southern Xizang. In: Liu GH et al. (eds), Geological Memoirs,Series 3. No.11 Tectonic Evolution of the lithosphere of the Himalayas. Metamorphics and igneous rocks in Xizang(Tibet), Beijing: Geological Publishing House. p 199-239

McDougall I and TM Harrison. 1999. Geochronology and thermochronology by the ${ }^{40} \mathrm{Ar} /{ }^{39} \mathrm{Ar}$ method. New York Oxford: Oxford University Press, $\mathrm{p}$ 16-93

Ding L. 2003. Paleocene deep-water sediments and radiolarian faunas: Implications for evolution of Yarlung-Zangbo foreland basin, southern Tibet. Science in China Series D46(1): 84-96 